\title{
Bigger, stronger, better: Fish transgenesis applications and methods
}

\author{
Ayşe Cebeci ${ }^{1 *}\left(\mathbb{D}\right.$, ilhan Aydın ${ }^{2}$, Anthony Goddard ${ }^{3}$
}

${ }^{1}$ Central Fisheries Research Institute, 61250 Yomra, Trabzon, Turkey.

${ }^{2}$ General Directorate of Agricultural Research and Policies, 06800 Cankaya, Ankara, Turkey.

${ }^{3}$ Pharmacogenetics, Royal Holloway, University of London, TW20 OEX, London, UK.

\section{Article History}

Received 16 December 2020

Accepted 25 December 2020

First Online 29 December 2020

\section{* Corresponding Author \\ Tel.: +905318410150 \\ E-mail: \\ ayse.cebeci@tarimorman.gov.tr}

\section{Keywords}

Transgenic fish

Gene delivery techniques

AquAdvantage salmon

Genome editing

Disease resistance

\begin{abstract}
Transgenesis has been applied to several species to benefit from them in different fields. As natural fish stocks decline and the world population increase, the application of transgenesis on commercial fish species takes more attention to reduce the limitations of aquaculture and meet the increasing food demand. Transgenesis has been applied to obtain a stable transgenic line with improved traits to date. In aquaculture, growth rate, cold resistance, and disease resistance of commercial fish species were enhanced by transgenesis and even one of them, AquAdvantage Salmon, took place markets in the North America. Also, transgenic fish were developed to evaluate the health impacts of chemicals in ecotoxicology and provide more options with new color variants in ornamental fisheries. Different approaches for generating transgenic fish have been performed successfully, but they still require some developments. More transgenic fish could take place in the market by developing more efficient techniques and informing consumers about these techniques to reduce their concerns. This review discusses the application fields of transgenic fish with examples and provides an overview of gene delivery techniques and transgenesis methods.
\end{abstract}

\section{Introduction}

Transgenic animals are genetically modified organisms (GMOs) with heritable changes to the genome by integration of exogenous DNA (transgene) into the host genomic DNA. Since the human growth hormone gene has been successfully transferred to goldfish (Carassius auratus) genome to produce the first transgenic fish, more than 35 species had been genetically modified in research laboratories worldwide (Zbikowska, 2003; Zhu et al., 1985). Most transgenesis studies were conducted on fish traits for sustainable aquaculture by various gene delivery and transgenesis techniques (Durham et al., 1987; Ju et al., 2003; Sarmasik et al., 2002; Shears, 1991). Transgenic fish with enhanced traits could provide a great benefit as food for the growing world population while it could be a dangerous product of biotechnology upon escaping accidentally to the environment. However, aquaculture could more contribute to the food demand of the increasing world population by advanced biotechnology. There are many factors related to the environment (water supply and quality, environmental impact, climate change, farming technologies) and also with the cultured organism itself (feed supply, diseases) that can affect the development of aquaculture (Gómez, 2018).

Certain characteristics of the fish could be improved through transgenesis for more sustainable and profitable aquaculture. It is possible to save enormous money by increasing the growth rate of the fish as well as cold and disease tolerance. In addition to aquaculture, transgenic fish could be developed as experimental models for biomedical research (Goldman 
et al., 2001; Ward \& Lieschke, 2002). The use of transgenic fish in research laboratories as an alternative to rodents could considerably reduce the exploitation of mammals, decrease costs, and accelerate the research process (Zbikowska, 2003). Furthermore, transgenic fish could be used in environmental monitoring, and ornamental fisheries (Amanuma et al., 2000; Ju et al., 2003). In this review, we described application areas of transgenic fish in aquaculture and mentioned some gene delivery techniques. Furthermore, we attempt to provide an overview of both traditional and modern transgenesis methods.

\section{Applications of Transgenic Fish}

\section{Transgenic fish in aquaculture}

\section{Growth enhancement}

Insertion of genes for growth enhancement has been applied to many fish species using different DNA constructs relating to the origin of the growth hormone gene and the promoter. During initial experiments conducted on fish in the 1980s, DNA constructs comprised of mammalian or viral promoters and mammalian growth hormone genes, but then the genes and promoters of piscine origin were used (Durham et al., 1987; Nam et al., 2001; Rahman et al., 1998; Zhu et al., 1985). Although transgenes derived from very distantly related species had no or only modest effects on growth in transgenic fish, transgenes from piscine species were shown to be more efficient (Betancourt et al., 1993; Penman et al., 1991). Significant growth enhancement by genetically modifying fish with an exogenous growth hormone gene is achieved for a few species including nile tilapia (Oreochromis niloticus), common carp (Cyprinus carpio), mud loach (Misgurnus mizolepis), coho salmon (Oncorhynchus kisutch), and rohu carp (Labeo rohita) (Barman et al., 2015; Devlin et al., 1994; Nam et al., 2001; Rahman et al., 1998; Zhang et al., 1990). Effect of transgene on growth rate could varied from 35 -fold increase in size compared with the non-transgenic counterparts, to almost no difference depending on the species and DNA constructs (Nam et al., 2001; Pitkänen et al., 1999a).

Considerably high growth rate effects (typically 6to 14-fold compared to controls) were observed for some salmonid species comprising Atlantic salmon (Salmo salar), Coho salmon, and Arctic charr (Salvelinus alpinus), but levels of growth enhancement were variable among transgenic salmonid lines (Devlin et al., 1994; Du et al., 1992; Pitkänen et al., 1999a). Extreme growth in salmonids carrying a transgene could be because of experiencing important seasonal reductions in growth while warm-water fish species naturally grow at near maximal rates during the year (Mori \& Devlin, 1999).

Although constructs containing permissive viral or piscine constitutive promoters usually increase growth rate, some constructs could not affect growth performance. For example, a construct consisting of the growth hormone 2 gene from Atlantic salmon and the homologous promoter ( $\mathrm{SsGH}_{2}$ ) did not affect the growth rate of rainbow trout (Oncorhynchus mykiss) expressing growth hormone only in the pituitary, the normal site of growth hormone expression (Pitkänen et al., 1999a). In a study, it was showed that growth enhancement could depend on the intrinsic growth rate and genetic background of the host strain (Devlin et al., 2001). Wild strains of rainbow trout naturally grow slowly while the growth rate is higher in selectively bred domesticated strains. Growth hormone construct was introduced into a wild and domesticated strain of rainbow trout, yet the introduction of the growth hormone construct into the domesticated strain did not cause further growth enhancement because this strain reaches maximal rate with the different genetic background (Devlin et al., 2001).

Upon DNA constructs were applied to fish, besides growth enhancement, other phenotypic changes in fish morphology, and some physiological abnormalities were observed in some species (Devlin, 1997). These could be an alteration of skin color, modifications of skull shape, acceleration of smoltification in salmonids, precocious sexual maturation, decreased fertility or even sterility, and reduced viability.

Several studies suggested that transgenic fish display considerable metabolic differences compared to non-transgenic siblings and their metabolism is more efficient (Krasnov et al., 1999; Martinez et al., 2000). For example, the juveniles of transgenic tilapia demonstrate increased protein synthesis and growth rate concomitant with enhanced glycolysis and oxidation of amino acids (Martinez et al., 2000). Also, transgenic charr showed enhanced metabolic activity and utilization of dietary lipids (Krasnov et al., 1999).

\section{The story of transgenic Atlantic salmon:}

The most well-known transgenic fish with an increased growth rate is the AquAdvantage Salmon developed by the group of Fletcher at Memorial University of Newfoundland (Gómez, 2018). This transgenic Atlantic salmon was created via microinjection of a DNA construct containing an antifreeze protein gene promoter from ocean pout (Macrozoarces americanus) and a Chinook salmon (Oncorhynchus tshawytscha) growth hormone cDNA (opAFP-GHc2) into fertilized eggs of wild Atlantic salmon (Du et al., 1992). Therefore, the line of transgenic Atlantic Salmon has a copy of transgene expressing continuously along with its salmon growth hormone gene expressing seasonally. Transgenic Atlantic salmon reach market size $(4-5 \mathrm{~kg})$ from eyed-egg stage in nearly 18 months compared to 36 months for conventionally farmed Atlantic salmon and also consume $25 \%$ less feed than conventionally farmed Atlantic salmon during the growth period (Gómez, 2018).

After a long journey through the US regulatory system, AquAdvantage Salmon is now produced by the company AquaBounty Technologies (Massachusetts, 
USA). The journey started in 1993 when AquaBounty first approached the U.S. Food and Drug Administration (FDA) to find out the requirement for approval of AquAdvantage Salmon as food, but a regulatory pathway did not exist for genetically engineered (GE) animals (Van Eenennaam \& Muir, 2011). The company appealed for regulation under FDA since they thought the difficult pathway for approval would contribute to addressing public concerns about food from GE animals. AquaBounty established an Investigational New Animal Drug (INAD) file with the Center for Veterinary Medicine (CVM) of the U.S. FDA to pursue the development of AquAdvantage Salmon in 1995. During the assessment period, AquaBounty Technologies constructed a landbased aquaculture facility (AquaBounty Panama) in the highlands of Panama to conduct trials of the Company's AquAdvantage Salmon (Aquabounty, 2020).

FDA released Guidance 187 for the regulation of GE animals in 2009 (Van Eenennaam \& Muir, 2011). Based on this guidance, the FDA applies a hierarchical riskbased approach to evaluate GE animals and their edible products in seven-step by investigating the safety of the recombinant DNA construct for the animal, the safety of food from the animal, and any environmental impacts and efficiency claimed for the animal in the seven-step (Sanderson and Humphries, 2015). Molecular characterization of the rDNA construct should be conducted to detect whether it includes DNA sequences from viruses or other organisms that could cause health risks to the GE animal or those consuming the animal (Van Eenennaam \& Muir, 2011). Also, molecular characterization of the GE animal lineage should be conducted to control the inherited stability of the rDNA construct in the next generations. Furthermore, the health state and development process of GE animals should be evaluated by phenotypic characterization comparing with non-GE animals (Sanderson \& Humphries, 2015). If the GE animal is proposed as a source of food as with the AquAdvantage salmon, FDA evaluates the composition of edible tissues and risk of allergenicity compared to their non-GE counterparts (Van Eenennaam \& Muir, 2011). FDA finally requires the preparation of an environmental assessment of the animal and of conditions suggested for raising the GE animal as stated in the product definition and the sponsor data supporting the claimed efficiency of GE animal (Van Eenennaam \& Muir, 2011).

Following the release of the Guidance, AquaBounty Technologies submitted its final regulatory study to the FDA completing all tests for evaluation (Aquabounty, 2020). After that, AquaBounty's Panama site was investigated and approved by the FDA for the production of AquAdvantage Salmon. FDA concluded that AquAdvantage Salmon is safe to eat; and poses no threat to the environment under its raising conditions and then FDA convened its Veterinary Medicine Advisory Committee (VMAC) in a public meeting to review its findings (Van Eenennaam \& Muir, 2011). The VMAC agreed with the FDA; AquAdvantage Salmon is safe to consume, and safe for the environment, therefore FDA completed a food safety assessment in 2010. The FDA consults with the National Marine Fisheries Service of NOAA and the U.S. Fish and Wildlife Service for more investigation on environmental impacts of AquAdvantage salmon in 2011(Aquabounty, 2020). These organizations agreed with the findings of the FDA that the AquAdvantage Salmon do not pose a threat to the environment. The FDA completed the environmental assessment and published in the Federal Register a preliminary Finding of No Significant Impact (FONSI) for AquAdvantage Salmon in 2012 (Gómez, 2018).

In 2011, AquaBounty Technologies also completed a New Substance Notification (Organisms) for AquAdvantage Salmon and applied it to Environment Canada. AquaBounty Technologies had continued its story in Canada by applying to the Canadian Food Inspection Agency in 2012 for registration of AquAdvantage Salmon as a Novel Feed and to Health Canada for a Novel Foods Pre-Market Submission (Aquabounty, 2020).

Environment Canada published a Significant New Activity Notice indicating AquAdvantage Salmon is not considered to be a risk to the environment in 2013 (Aquabounty, 2020). Therefore, AquaBounty Technologies receives authorization for the production of eggs at AquaBounty Canada's hatchery for commercial sale. However, Ecojustice on behalf of Ecology Action Centre and Living Oceans Society files lawsuit against the Canadian federal government (Health Canada, Environment Canada) and AquaBounty for permission to produce genetically modified salmon in Canada. Similar actions by non-governmental organizations also occurred when the FDA evaluating the environmental impacts of AquAdvantage salmon (Van Eenennaam \& Muir, 2011).

The main environmental concern about AquAdvantage fish is the possibility of escape and cause the collapse of wild salmon populations. Environmental concerns could be mitigated by land-based production with physical confinement barriers and also biological measures resulting in $99 \%$ sterility and $100 \%$ female production stocks (Van Eenennaam \& Muir, 2011). In principle, there is no difference between potential environmental risks related to the escape of transgenic fish and those related to the annual escape of a lot of farmed selectively bred fish. Matings between escaped farmed salmon and wild native fish could cause a substantial risk of extinction for natural populations, but the comparative risk of sterile transgenic AquAdvantage salmon is probably to be less than that of fertile, selectively bred, Atlantic salmon (Van Eenennaam \& Muir, 2011).

AquAdvantage Salmon was approved by the FDA for consumption in the USA in 2015 (Gómez, 2018). After a while, the import of AquAdvantage Salmon into the USA was prohibited until labeling requirements were announced by FDA (Van Eenennaam, 2017). The 
U.S. Congress passed a GMO food labeling bill and give 2 years to USDA to establish a labeling language and guidelines. Meanwhile, Health Canada approved the production, sale, and human consumption of AquAdvantage Salmon in Canada. Following those approvals, AquaBounty Technologies purchased certain assets of the Bell Fish Company LLC farm site in Albany, Indiana to establish the first commercial-scale production facility in the United States in 2017 (Figure 1) (Aquabounty, 2020).

The FDA approved to raise AquAdvantage Salmon at the Company's Indiana farm in 2018 (Aquabounty, 2020). After establishing of labeling language and guidelines for GMO food, the FDA allowed the Company to start farming AquAdvantage Salmon in Indiana in 2019. Also, the company gained permission from Environment and Climate Change Canada (ECCC) for the commercial production and grow-out of AquAdvantage Salmon in Rollo Bay facility. At the end of the tortuous journey, AquAdvantage Salmon reached to market in the USA as well as in Canada. The market of AquAdvantage Salmon would probably extend through projects conducted by AquaBounty Technologies in Brazil, Argentina, Israel, and China starting new journeys (The Fish Site, 2020).

AquAdvantage Salmon could also continue its journey in Europe. First, it should take proper scientific opinion from the European Food Safety Authority (EFSA) agency which provides independent scientific advice on current and emerging risks to food safety in the European Union (EU) (Slyck, 2017). A guidance on the environmental risk assessment of GE animals were published by EFSA to present information for applicants and risk assessors on placing GE animals on the EU market. EU regulatory system adopts precautionary principle for releasing of GE animals in constrast to FDA adopting prevention principle. Precautionary principle aims a high standard of environmental protection via preventative decision-making if risks are reasonably suspected. Based on this principal difference, AquAdvantage salmon is ban now in the EU, but this situation could change with the positive results of long- term effects of GE animals on enviroment and food safety, and also trade agreements (Debode et al., 2018).

\section{Cold resistance}

Many species of polar and northern fish inhabiting frigid water such as winter flounder (Pleuronectes americanus) and ocean pout produce antifreeze proteins to protect them from freezing (Lee et al., 2013). Based on their structural features, four types of antifreeze proteins (AFPs; type I, II, III, and IV) were characterized from teleosts as well as antifreeze glycoproteins (AFGPs) (Lee et al., 2013). These proteins bind to the ice surface to prevent the growth of ice crystals by decreasing the freezing temperature. Generation of freeze-tolerant transgenic salmon or other species via the introduction of an AFP gene could greatly improve fish farming in northern latitudes.

The idea of producing transgenic fish with cold tolerance was actually motivated by the possibility of culturing Atlantic salmon along the East coast of Canada (Gómez, 2018). The Atlantic salmon is incapable to survive in sub-zero seawater temperature due to the lack of any of these AFGPs or AFPs gene(s) (Hew et al., 1995). This inability cause one of the major problems of sea cage farming in the northern Atlantic coast severely limiting the selection of suitable sites for operation. To solve this problem, winter flounder type I AFPs that have two isoforms, liver-type, and skin-type, could be good candidates for gene transfer. The former type mainly is produced in the liver as precursor proteins (preproAFPs) that need to be further processed while the latter type is produced in peripheral tissues as intracellular, mature AFPs (Hew et al., 1999). The AFP gene for type I AFP from winter flounder were inserted into Atlantic salmon genome under its promoter and expressed at a level of $0.1-50 \mu \mathrm{g} / \mathrm{ml}$ (Shears, 1991). Another study generated a stable transgenic line of Atlantic salmon by incorporating one copy of the winter flounder liver-type AFP gene into the genome of Atlantic salmon and the expression of the transgene was stable (approximately $250 \mu \mathrm{g} / \mathrm{ml}$ ) up to the F3 generation (Hew et al., 1999). ProAFP was expressed only in the liver and display seasonal variations similar to those in winter flounder.

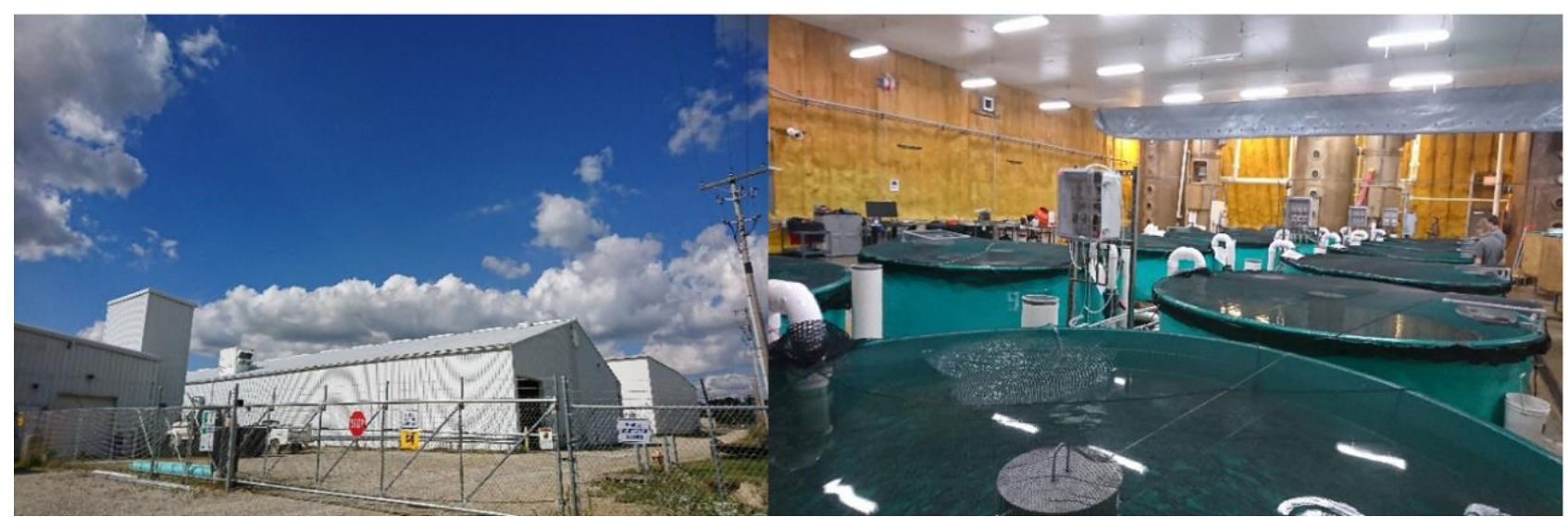

Figure 1. AquaBounty Technologies farm in Albany, Indiana established as first commercial-scale production facility of AquAdavantage Salmon. 
The antifreeze activity was found in the sera of F3 offspring despite the lack of necessary processing enzymes to process proAFP precursor into a mature protein, but low-level production of AFP remained a problem (Hew et al., 1999).

Similar approaches were also conducted on goldfish by integrating the type III AFP gene from ocean pout encoding a mature protein into its genome (Wang et al., 1995). In this model, a mature AFP was produced in F1 and F2 offspring, and the transgenic goldfish showed better tolerance to cold water compared with the control group. Likewise, nile tilapia become resistant to temperatures as low as $13^{\circ} \mathrm{C}$ by injection or oral administration of AFP to juveniles or adults (Wu et al., 1998). This suggests that transgenic tropic species could be farmed in cold areas by the integration of AFP into their genome from other species, but low-level production of AFP decreases the efficiency of this approach. Whilst the expression level of AFP in winter flounder is generally approximately $10-20 \mathrm{mg} / \mathrm{ml}$, all transgenic fish for AFP only express in the $\mu \mathrm{g} / \mathrm{ml}$ range (Zbikowska, 2003). An increase in the copy number of the transgene or the use of constructs with other AFPs could increase expression and help to enhance freezeresistance in farm fish.

\section{Disease resistance}

One of the promising application areas of gene transfer in aquaculture is the development of disease resistance. In aquaculture, diseases are an important problem disrupting animal welfare and leading to great economic losses. Transgenic fish with increased disease resistance could improve the profitability, production, efficiency, and welfare of the cultured fish (Dunham, 2009).

One approach to increase resistance against bacterial pathogens is to transfer antibacterial peptide genes. This approach was applied to Channel catfish (Ictalarus punctatus) by the transfer of a DNA construct containing a lytic peptide, cecropin $B$, driven by a cytomegalovirus (CMV) promoter and transgenic fishes showed two and four-fold increases in resistance against Edwardsiella ictaluri and Flavobacterium columnare, respectively (Dunham et al., 2002). Also, no difference in growth rate was observed between the transgenic and nontransgenic siblings. Another example of increasing bacterial resistance through transgenesis is the transfer of cecropin genes to medaka (Oryzias latipes) using various DNA constructs (Sarmasik et al., 2002). At the F2 generation, transgenic medaka from different families were challenged with Psuedomonas fluorescens and Vibrio anguillarum, and then transgenic lines showed 0$10 \%$ and $10-30 \%$ cumulative mortality, respectively. The enhanced disease resistance showed a difference between transgenic families, which means family variation could be important due to differences in the genetic background (Dunham, 2009). This emphasizes combining gene transfer with selection to provide maximum genetic gain from the gene transfer. Besides antibacterial peptides, other proteins with antimicrobial properties could be used to enhance disease resistance. $B$ actin-human lactoferrin gene was transferred to grass carp (Ctenopharyngodon idellus) and then P1 individuals were more resistant to Aeromonas with increased phagocytic activity (Mao et al., 2004).

Another approach is to enhance the expression of a piscine lysozyme as an antibacterial agent against some fish pathogens. Yawaza et al. (2006) produced F2 transgenic zebrafish (Danio rerio) using a DNA construct including hen egg white (HEW) lysozyme gene and green fluorescence protein (GFP) gene driven by Japanese flounder (Paralichthys olivaceus) keratin promoter. Expression of both HEW lysozyme gene and GFP gene was detected in the liver and protein extracts from the liver of F2 transgenic fish showed 1.75 times higher lytic activity than in the controls. In a challenge experiment with Flavobacterium columnare, $65 \%$ of the F2 transgenic fish survived while $100 \%$ of the control fish were killed (Yawaza et al., 2006). Similarly, $60 \%$ of the F2 transgenic fish survived during a challenge test with Edwardsiella tarda, while $100 \%$ of the control fish died.

To prevent viral diseases in aquaculture, the common gene transfer approach is to use viral antisense RNAs or DNA-vaccines. However, the application of these techniques does not create exactly transgenic fish because these DNA/RNA constructs could not be passed to the next generation, instead, these techniques play a role in the gene expression of fish. Antisense RNA approach was applied to prevent infectious pancreatic necrosis virus pathogenicity by hammerhead ribozyme cleavage in vitro (Chen et al., 2000). The first DNA vaccine was produced against infectious hematopoietic necrosis using its the glycoprotein gene and tested on rainbow trout (Anderson et al., 1996). Since then, mono and multivalent DNA vaccines were applied to many fish species to protect against viral and bacterial pathogens (Kumar et al., 2008; Pereiro et al., 2012; Sun et al., 2012).

\section{Transgenic fish in ecotoxicology}

Transgenic fish, particularly transgenic zebrafish, have significant potential use in aquatic ecotoxicology as biosensors and models providing information on health effects of chemical exposure, but the use of transgenic fish in environmental toxicology is not common (Lee et al., 2014). Biosensor fish work in the principle of stimulation of specific genes, often enzymes or receptors, by certain chemicals/pollutants (Zbikowska, 2003). Transgenic fish could detect environmental pollutants in water and then induce a reporter gene driven by an element activated by low levels of pollutants. Transgenic fish lines developed to research contaminants and other environmental stressors include cadmium and copper toxicity by induction of heat-shock protein gene, oxidative stress via the induction of an electrophile-responsive element (EpRE), various organic chemicals interacting with the aryl hydrocarbon receptor-mediated toxicity, and estrogenicity (vitellogenin, choriogenins, estrogen 
receptor-responsive elements) generally using either luciferase or GFP as reporter genes (Blechinger et al., 2002; Kusik et al., 2008; Lee et al, 2014; Mattingly et al., 2001; Petersen et al., 2013; Zeng et al., 2005). Transgenic biosensor fish were created by using the heat-shock protein ( $h s p$ ) promoters, promotors of $h s p 70$ and hsp27, stimulated by various environmental stressors such as temperature and heavy metals (Lee et al., 2014). Transgenic zebrafish using hsp 70 gene promoter to control eGFP (enhanced green fluorescent protein) as the reporter gene was exposed to cadmium and was sensitive at concentrations as low as $0.2 \mu \mathrm{M}$ (22.5 $\mu \mathrm{g} / \mathrm{L})$ (Blechinger et al. 2002).

The promoter of the cyp1a1 gene was used to control a GFP reporter gene for detection of exposure to organic chemicals in transgenic zebrafish and medaka (Hung et al. 2012; Kim et al. 2013; Lee et al, 2014; Ng \& Gong 2013). Cyp1a1 is a member of the cytochrome P450 superfamily and has a role in the oxidative metabolism of diverse organic substances including polycyclic aromatic hydrocarbons (PAHs) and polychlorinated biphenyls (PCBs) (Ma \& Lu, 2007). Transgenic Cyp1a - GFP medaka embryos exposed to 2,3,7,8-tetrachlorodibenzo- $p$-dioxin (TCDD) for 24 hours and then GFP expression was detected in kidney, liver, and gut at an exposure concentration of only 0.005 $\mathrm{nM}$ (1.6 ng/L) (Ng \& Gong, 2013). Also, this transgenic medaka expressed the GFP reporter gene in the liver and kidney when exposure to other PAHs including 3methylcholanthrene (3-MC) and benzo[a] pyrene (BaP).

Furthermore, transgenic fish could be used for mutation assays to evaluate potential DNA damage after exposure to chemicals in aquatic environments. Transgenic medaka developed by Winn et al. (2000) harbors bacteriophage $\lambda$ LIZ vector containing the lacl or cll bacterial gene as mutational targets. Also, mutation assays based on plasmid vectors were designed such as zebrafish carrying the $\mathrm{pML} 4$ plasmid vector fused to $r s p L$ gene (Amanuma et al., 2000). Thanks to the valuable features of fish as test organisms, transgenic fish could make important contributions to ecotoxicology studies.

\section{Transgenic fish in Ornamental Fisheries}

Ornamental aquaculture is a growing commercial sector with more than 4500 freshwater species and 1450 marine species traded worldwide (Stevens et al., 2017). Ornamental fish trade is a significant source of income for a lot of countries including Singapore, Malaysia, Thailand, and Indonesia while USA is the largest importer of Ornamental fish (Satam et al., 2018). Although accurate information about total value of the sector is lack, estimated total value of the sector varies between U.S. $\$ 800$ million and $\$ 30$ billion annually and the amount of traded fish is considered to be between 350 million and 1.5 billion live fishes (Stevens et al., 2017). Development of species with new features by transgenesis could contribute to the growth of this sector presenting customers with new options.
Transgenesis is applied on ornamental fish species to produce transgenic fish with different color forms. Color genes showed stable expression in zebrafish embryos injected with GFP expression constructs under the control of the zebrafish muscle-specific promoter of the myosin light polypeptide 2 (mylz2) gene (Ju et al., 2003). Then fluorescent white skirt tetra (Gymnocorymbus ternetzi), medaka, and farmed rohu carp were successfully produced using the zebrafish mylz2 promoter (Mohanta et al., 2014; Pan et al., 2008; Zeng et al., 2005). 'GloFish' with six attractive fluorescent color combinations, including Starfire red, cosmic blue, electric green, galactic purple, sunburst orange and moonrise pink have been already presented to the market as commercial value-added aquarium fishes by transgenesis (Figure 2) (Vick et al. 2012).

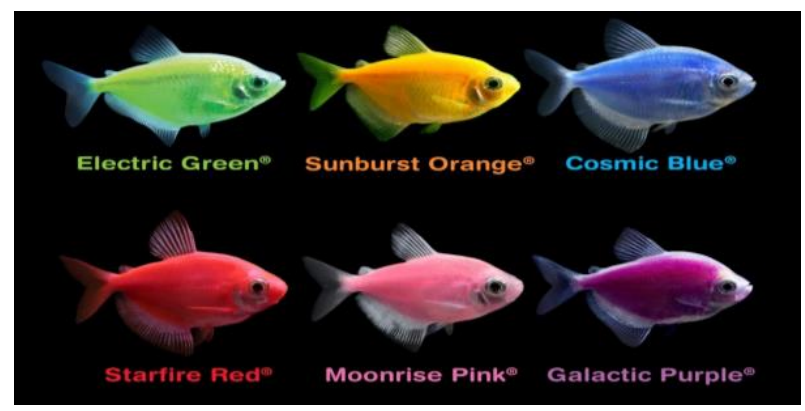

Figure 2. 'GloFish' with six attractive fluorescent color combinations, including Starfire red, cosmic blue, electric green, galactic purple, sunburst orange and moonrise pink as ornamental transgenic fish (Spectrum Brand Pet, 2020).

\section{Gene Delivery Techniques in Fish}

\section{Microinjection}

Microinjection of DNA into eggs or embryos at the one-cell stage is the most commonly applied gene transfer method in aquaculture (Pitkänen et al., 1999b; Cheers and Ettensohn, 2004). This technique was first used on goldfish for injection of foreign DNA into embryos and then applied on a variety of fish species such as common carp, atlantic salmon, medaka, tilapia, rainbow trout, and zebrafish to improve traits by gene transfer (Dunham et al., 1987; Hew et al., 1992; Ozato et al., 1986; Penman et al., 1991; Xu et al., 2008; Rahman et al., 1998; Rasal et al., 2016; Zhu et al., 1985).

Characteristics of eggs affect the application of microinjection and gene transfer efficiency. Fish eggs could have tough and opaque chorion which prevents insertion of glass micropipettes leading to low gene transfer efficiency rate (Dunham et al., 1987; Sin et al., 1997). Also, transgene could be injected into the cytoplasm of the egg because the nuclei of eggs could be small and hard to visualize. Limitations related to tough and opaque chorion dealed with injection into oocyte nuclei after making a hole in salmonids called two-step injection (Rasal et al., 2016). Eggs could be dechorionated manually or using trypsin or pronase to ease the insertion of pippets. Injection pipettes are chosen depending on the egg size of species to prevent 
mortality because of mechanical damage on fertilized eggs (Tonelli et al., 2017a). In order to enhance the efficiency of the selection of transgenics, genetic markers could be co-injected with the transgene to monitor zygotes as using of GFP as a marker in zebrafish (Peters et al., 1995).

Beyond problems related to characteristics of eggs, the microinjection method is time-consuming since microinjection of a transgene is operated on only one embryo after another (Singh et al., 2019). It even requires a great deal of technical skill and comparatively expensive types of equipment including micromanipulators and microinjectors. Despite these mentioned limitations, microinjection is a favored technique for gene transfer with a success rate ranging from $10 \%-70 \%$ in fishes (Powers et al., 1991).

\section{Electroporation}

Electroporation, the use of high-voltage electric shocks to introduce DNA into cells, is a procedure that is popular for introducing foreign genetic material into the cells of many different organisms (Potter and Heller, 2018). The standard protocol for all organisms involves cells being suspended in an appropriate, conducting buffer with the foreign gene being transfected, and then high-voltage electric shocks are used to make the cells more porous, allowing the introduction of the foreign gene into the cell. Transfected cells are then diluted and initially cultured in a non-selective medium. Afterward, appropriate selection is added, and cells are then separated and assessed for the introduction of the transgene (Potter and Heller, 2018).

Electroporation can be used to introduce transgenes in aquaculture. Either by inserting the transgene into spermatozoa (Celebi et al., 2003) or oocytes (Grabarek et al., 2002) before fertilization or by direct insertion into fertilized embryos (Kera, Agerwala and Horne, 2010). These have been applied with success in vivo results in salmon with observed mosaicism of the fish (Sin et al., 2000), shrimp (Arenal et al., 2000), nile tilapia (Lin, Chang and Chen, 2016), and medaka with changes being transferred through the germline (Hostetler, Peck and Muir, 2003).

The success of electroporation has shown to be extremely influential for zebrafish developmental biology studies. One example involves introducing a CRISPR/Cas9 plasmid to knockdown the gene Mctp2p to characterize its effect on neuronal and muscular development in zebrafish embryos (Espino-Saldaña et al., 2020). Electroporation is a diverse method with many potential applications for the development of transgenic fish.

\section{Transgenesis Tools}

\section{Transposon Vectors}

Transposable elements are a valuable tool to integrate genes into chromosomes to provide new traits. A transposon system usually contains a transgene sequence flanked by transposon-inverted repeats and the transposase-coding sequence (Tonelli et al., 2017a). Sleeping Beauty, Tol2, and piggyBac are commonly applied transposons for fish.

Transposon systems first were used on fish when a Caenorhabditis elegans transposon (Tc3 element from the Tc1/mariner family) system was injected into onecell-stage eggs to integrate GFP into the zebrafish genome (Raz et al., 1997; Tonelli et al., 2017a). Tol2 element, derived from the medaka genome, was also used on zebrafish to deliver various genes (CFP/YFP/RFP or Gal4 cassettes) and this study provided new protocols to rapidly apply Tol2 mediated zebrafish transgenesis (Bussmann \& Schulte-Merker, 2011). Application of Sleeping Beauty transposon on zebrafish to transfer a blue-shifted GFP variant and a red fluorescent gene in a tissue-specific manner enhanced the transgenesis and expression rate sixfold (from 5 to $31 \%$ ) compared to standard, plasmid injection-based transgenesis methods (Davidson et al., 2003). Applicability of the transposon piggyBac for transgenesis was showed on goldfish and loach (Hu et al., 2012).

Transposon vectors have a few advantages for transgenesis in fish compared to plasmid and viral vectors. Transposon vectors provide the insertion of a single, defined DNA sequence into the genome without absolute size restrictions instead of a multi-copy of sequence observed use of plasmid vectors (Hackett et al., 2004). However, possible active copies of the corresponding transposases might prevent insertion and enhanced stability of transgenes in fish such as salmonids (Tafalla et al., 2006).

\section{Viral Vectors}

Infection by viruses is a well-established gene delivery tool still used for transgenesis due to efficient integration and usually single-copy insertion of genetic material into the host genome. When retroviruses and lentiviruses are internalized into the target cell, their genetic material (RNA) is transformed to DNA, thereby their genetic information is inserted into the host genome (Tonelli et al., 2017a). After transduction efficiency of pseudotyped viruses was displayed on zebrafish in 1994, this method was applied on various fish species including nile tilapia and live-bearing fish (Poeciliposis lucida) to integrate transgene into the fish genome (Lin et al., 1994; Sarmasik et al., 2001; Tonelli et al., 2017b).

In order to improve this method for transgenesis in aquaculture, a number of viral gene delivery studies were conducted on zebrafish and medaka due to their transparent embryos (Tonelli et al., 2017a). Zebrafish cells were infected by vesicular stomatitis virus (VSV)glycoprotein envelope including a genome obtained from the Moloney murine leukemia virus (MLV) and studies showed the degree of transduction efficiency expanded as the titer elevated and transmittable insertions could be enhanced in zebrafish by selecting virus-producer cell lines (Chen et al., 2002; Gaiano et al., 
1996; Lin et al., 1994). Also, transgenic zebrafish could be produced by applying viral gene delivery into the sperm culture and then performing in vitro fertilization (Kurita et al., 2004). Baculovirus system as that used on zebrafish could be used as an alternative to retrovirus and lentivirus because they provide increased control of the transduced region and exact determination of gene expression time using various promoters on DNA constructs (Wagle \& Jesuthasan, 2003).

Despite the higher transduction efficiency of gene delivery by viral vectors, this method has some important disadvantages. Transgenes transferred by a viral vector could show unstable expression or even complete silencing of the transgene (Rasal et al., 2016). The reason for silencing of the transgene is that activation of gene repression machinery in the host cells through the promoter and enhancer sequences of the retroviral long-terminal-repeats (LTRs), followed by hypermethylation of the viral promoter sequences by de novo DNA methylation (Jahner and Jaenisch, 1985). Owing to the small size of viral vectors, generally, $10 \mathrm{~kb}$ transgene could be package into viral vectors, which restrict the transfer of larger genes by this method (Robl et al. 2007). Also, infection of early embryos usually shows a delay in transgene integration, thus producing mosaic animals that is because the breakdown of the nuclear membrane during mitosis is necessary for infection by retroviruses (Robl et al. 2007). Even though limitations of this method could be solved, the public may not accept transgenic fish as food produced by an integration of viral sequences because of biosafety and ethical issues (Rasal et al., 2016).

\section{$\underline{\text { Tools for site-specific integration }}$}

In contrast to transgenesis, which involves the transfer of a gene from one organism to another, genome editing allows specific, targeted, and often minor changes to the genome of the species of interest. Three methods have been predominantly utilized to conduct genome editing. Zinc-finger nucleases (ZFNs), transcription activator-like effector nucleases (TALENs), and clustered regularly interspaced short palindromic repeats (CRISPR).

The earliest developed programable method of gene editing involves utilising a group of nucleases called zinc-finger nucleases (ZFNs). ZFNs are hybrids between a nonspecific DNA-cleavage domain and a DNA-binding domain composed of $\mathrm{Cys}_{2} \mathrm{His}_{2}$ zinc fingers. These nucleases have been used to stimulate homologous recombination of DNA, allowing the introduction of mutations (Bibikova et al., 2001). ZFNs have increased the efficiency of introducing foreign genetic material to the DNA of higher eukaryotes from approximately 1 for each $10^{6}$ cells treated to nearly $100 \%$ of all cells treated. Gene editing is conducted by co-injecting to nuclease and DNA into the cells. ZFNs then cut specific restriction sites within the cell DNA and the introduced DNA is introduced via homologous overhangs, allow specific, site-directed mutagenesis
(Bibikova et al., 2001). This technique has been used to introduce targeted mutations in vivo in many species including Drosophila (Bibikova et al., 2002) and zebrafish with mutations being carried through the germline for zebrafish (Foley et al., 2010). More recently, ZFNs have been applied in vivo to species of interest to aquaculture such as editing the luteinising hormone in channel catfish to create sterile fry (Qin et al., 2016) Notable limitations of gene editing through use of ZFNs include the need for specific restriction sites to be present within the gene of interest as well as two restrictions sites being located within 6 to $18 \mathrm{bp}$ of each other (Bibikova et al., 2001). This restricts the capacity for developing point mutations and small edits within the genome using this technique and necessitates the application of other techniques to achieve these changes.

Transcription activator-like effector nuclease (TALENs) was later developed after the discovery of the transcription activator-like (TAL) family of proteins in the plant pathogenic bacteria Xanthamonas (Boch and Bonas, 2010). TALENs could be used for genome editing by inducing double-strand breaks (DSB), which activate repair mechanisms of cells (Joung \& Sander, 2012). Nonhomologous end joining (NHEJ) ligates DNA from either side of a double-strand break where there is little, or no sequence overlap for annealing. This induces errors in the genome via indels (insertion or deletion), or chromosomal rearrangement, resulting in a nonfunctional gene (Miller et al., 2011). TALENs has successfully been applied in vivo to edit the genome of aquaculture species including editing oestrogen production in nile tilapia (Li et al., 2013). A major limitation to the application of TALENs in aquaculture is that the mechanism of NHEJ only ablates genes and cannot create point mutations (Miller et al., 2011). This restricts gene editing to those genes where loss of function is beneficial while other methods of gene editing will be required where change or increase in function is required.

The most novel method of gene editing methods is CRISPR which uses the Cas family of proteins to introduce breakage to the DNA of the target organism allowing the introduction of genetic edits (Jinek et al., 2012). CRISPR and accompanying Cas proteins constitute an adaptive antiviral immune system in bacteria and archaea (Barrangou, 2015). The CRISPR defense system allows bacteria and archaea to recognize specific sequences and degrade them to prevent viral infection. CRISPR-Cas immune responses proceed in three stages: adaptation, where pieces of DNA are sampled from the invasive genetic material and are acquired into CRISPR loci for the purposes of immunity and immune memory, expression through transcription and processing of interfering CRISPR RNAs (crRNA), and interference through Cas directed cleavage of the invasive genetic material.

A subset of the CRISPR immune system response which utilizes mature crRNA base-paired to trans- 
activating tracrRNA to form an RNA structure that directs CRISPR-associated protein Cas9 has been exploited for the purposes of gene editing (Jinek et al., 2012). The CRISPR/Cas9 gene-editing system creates site-specific double-stranded breaks in target DNA. Genes are edited by incorporating a target sequence with a neighbouring protospacer adjacent motif (PAM) specific to Cas9 into the guide RNA (gRNA) of the Cas9 vector. The Cas9 vector is then inserted into the target cells where it encodes for the gRNA and the Cas9 protein. The gRNA directs the Cas9 to the target DNA where the Cas9 creates a double-stranded break at the PAM site and the cells naturally repair the DNA using NHEJ. This mechanism is often inaccurate, leading to random insertions and deletions, and causing frameshifts in the target gene, which can knock out the entire gene. More targeted mutagenesis can be achieved by utilizing homology-directed repair (HDR). This process requires a homology-containing donor DNA sequence to be coinserted with the Cas9 vector to facilitate repair (Zhang et al., 2014). This sequence can contain specific mutations which will then be incorporated into the modified DNA as it repairs, creating potentially "error-free" mutagenesis.

Multiple gRNAs can also be incorporated into a single CRISPR/Cas9 vector, inducing multiple mutations within a genome or a single gene (Sakuma et al., 2014). This multiplexing system has been demonstrated in mammalian genomes as well as those of zebrafish, drosophila, Caenorhabditis elegans and bacteria (Zhang et al., 2014). However, CRISPR/Cas9 can also risk cleavage of highly homologous sites other than those intended, creating off-target mutations, and is entirely dependent on the location of a PAM site. This makes the selection of the gRNA sequence extremely important to minimize these risks.

CRISPR editing has successfully been applied in vivo to many species including those relevant to aquaculture research (Table 1). These include modification of immune function in rohu carp (Chakrapani et al., 2016) and growth in channel catfish (Khalil et al., 2017) and rainbow trout (Cleveland et al., 2018) and the pacific oyster (Crassostrea gigas) (Yu et al., 2019) with germline transmission of these gene edits being observed in channel catfish (Khalil et al., 2017).

\section{Conclusion}

Classical genetic studies were used to improve fish stocks providing valuable information about genetic traits. Nevertheless, scientists started to engineer a particular genetic trait in a directed way with the discovery of recombinant DNA technology and the development of gene transfer techniques. Therefore, transgenesis for enhancement of traits in a directed fashion started a new era in aquaculture. Transgenic fish have many significant biotechnological applications in several fields including aquaculture. Transgenic fish have been generated with enhanced growth rate, cold tolerance, and disease resistance for aquaculture. Also, transgenic fish have been developed for environmental monitoring and ornamental fisheries. Microinjection was used commonly as a gene delivery method despite its some disadvantages. Viral vectors or transposons are efficient transgenesis techniques, but DNA sequence randomly integrates into the genome that might disrupt a functional gene in the host using these techniques. This problem could be solved by using tools such as ZFNs, TALENs, CRISPR/Cas to achieve site-specific integration. These tools have successfully been applied to improve traits of fish stocks, but they have important disadvantages like off-target effect. Following biotechnological advances, new techniques with the increased efficiency and effectiveness will be proposed to generate transgenic fish solving problems related to current methods.

Besides technical problems, environmental risk and human safety aspects of transgenic fish should be considered. Environmental risk could be mitigated using inland farms and sterile animals as AquAdvantage salmon. Food-safety issues are dealing with regulatory agencies, but the fate of transgenic fish as food will be determined by consumers in the long term. While research on the generation of transgenic fish continues, consumers could be informed by education and campaign on technology for transgenic fish production to reduce their concerns.

\section{References}

Arenal, A., Pimentel, R., Guimarais, M., Rodriguez, A., Martinez, R. and Abad, Z. (2000) Gene transfer in shrimp

Table 1. In vivo CRISPR editing of organisms relevant to aquaculture studies

\begin{tabular}{|c|c|c|c|c|c|}
\hline Species & Trait of interest & $\begin{array}{c}\text { Method of } \\
\text { introduction }\end{array}$ & NHEJ/HDR & $\begin{array}{c}\text { Germline } \\
\text { transmission }\end{array}$ & References \\
\hline Labeo rohita & Immune fuction & Microinjection & HDR & No & (Chakrapani et al., 2016) \\
\hline Ictalurus punctatus & Growth & Microinjection & NHEJ & Yes & (Khalil et al., 2017) \\
\hline Crassostrea gigas & Growth & Microinjection & NHEJ & No & (Yu et al., 2019) \\
\hline Pagrus major & Growth & Microinjection & NHEJ & No & (Kishimoto et al., 2018) \\
\hline Salmo salar & Sterility & Microinjection & NHEJ & No & (Wargelius et al., 2016) \\
\hline Oncorhynchus mykiss & Growth & Microinjection & NHEJ & No & (Cleveland et al., 2018) \\
\hline Exopalaemon carinicauda & Molting & Microinjection & HDR & Yes & (Gui et al., 2016) \\
\hline Oreochromis niloticus & Reproduction & Microinjection & NHEJ & Yes & (Li et al., 2014) \\
\hline
\end{tabular}


(Litopenaeus schmitti) by electroporation of single-cell embryos and injection of naked DNA into adult muscle. Biotecnologia Aplicada, 17(4), 247-250.

Amanuma, K., Takeda, H., Amanuma, H., \& Aoki, Y. (2000). Transgenic zebrafish for detecting mutations caused by compounds in aquatic environments. Nature Biotechnology, 18(1), 62-65.

Anderson, E. D., Mourich, D. V., \& Leong, J. C. (1996). Genetic immunization of rainbow trout (Oncorhynchus mykiss) against infectious hematopoietic necrosis virus. Molecular Marine Biology and Biotechnology, 5, 114-22.

Aquabounty (2020). Retrieved 13 December 2020, from https://aquabounty.com/wp-

content/uploads/2014/01/Chronology-of-

AquAdvantage-Salmon-F1.pdf.

Barrangou, R. (2015) The roles of CRISPR - Cas systems in adaptive immunity and beyond. Current Opinion in Immunology, 32, 36-41.

Barman, H.K., Mohanta, R., Patra, S.K., Chakrapani, V., Panda, R.P., Nayak, S., Jena, S., Jayasankar, P., \& Nandanpawar, P. (2015). The $\beta$-actin gene promoter of rohu carp (Labeo rohita) drives reporter gene expressions in transgenic rohu and various cell lines, including spermatogonial stem cells. Cellular and Molecular Biology Letters, 20(2), 237-247.

Betancourt, O. H., Attal, J., Theron, M. C., Puissant, C., \& Houdebine, L. M. (1993). Efficiency of introns from various origins in fish cells. Molecular Marine Biology and Biotechnology, 2, 181-188.

Bibikova, M., Carroll, D., Segal, D.J., Trautman, J.K., Smith, J., Kim, Y.-G., \& Chandrasegaran, S. (2001). Stimulation of Homologous Recombination through Targeted Cleavage by Chimeric Nucleases. Molecular and Cellular Biology, 21(1), 289-297.

Bibikova, M., Golic, M., Golic, K.G., \& Carroll, D. (2002). Targeted Chromosomal Cleavage and Mutagenesis in Drosophila Using Zinc-Finger Nucleases. Genetics, 161(3), 1169-1175.

Boch, J., \& Bonas, U. (2010). Xanthomonas AvrBs3 family-type III effectors: Discovery and function. Annual Review of Phytopathology, 48, 419-436.

Bussmann, J., \& Schulte-Merker, S. (2011). Rapid BAC selection for tol2-mediated transgenesis in zebrafish. Development, 138(19), 4327-4332.

Celebi, C., Guillaudeux, T., Auvray, P., Vallet-Erdtmann, V., \& Jégou, B. (2003). The making of "transgenic spermatozoa". Biology of reproduction, 68(5), 14771483.

Chakrapani, V., Patra, S. K., Panda, R. P., Rasal, K. D., Jayasankar, P., \& Barman, H. K. (2016). Establishing targeted carp TLR22 gene disruption via homologous recombination using CRISPR/Cas9. Developmental \& Comparative Immunology, 61, 242-247.

Cheers, M.S., \& Ettensohn, C.A. (2004). Rapid microinjection of fertilized eggs. Methods Cell Biology, 74, 287-310.

Chen, J. Y., Chen, J. Y., Chu, W. K., Wu, H. N., Hsu, Y. L., \& Wu, J. L. (2000). Infectious pancreatic necrosis virus RNA cleavage in vitro by hammerhead ribozymes and enhancement of ribozyme catalysis by oligonucleotide facilitators. Marine Biotechnology, 2(4), 364-375.

Chen, W., Burgess, S., Golling, G., Amsterdam, A., \& Hopkins, N. (2002). High-through put selection of retrovirus producer cell lines leads to markedly improved efficiency of germ line-transmissible insertions in zebra fish. Journal of Virology, 76(5), 2192-2198.
Cleveland, B. M., Yamaguchi, G., Radler, L. M., \& Shimizu, M. (2018). Editing the duplicated insulin-like growth factor binding protein-2b gene in rainbow trout (Oncorhynchus mykiss). Scientific reports, 8(1), 1-13.

Davidson, A.E., Balciunas, D., Mohn, D., Shaffer, J., Hermanson, S., Sivasubbu, S., Cliff, M. P., Hackett, P. B., \& Ekker, S. C. (2003). Efficient gene delivery and gene expression in zebrafish using the Sleeping Beauty transposon. Developmental Biology, 263(2), 191-202.

Debode, F., Janssen, E., Marien, A., Devlin, R., Lieske, K., Mankertz, J., \& Berben, G. (2018). Detection of Transgenic Atlantic and Coho Salmon by Real-time PCR. Food Analytical Methods, 11(9), 2396-2406.

Devlin, R. H., Yesaki, T. Y., Biagi, C. A., Donaldson, E. M., Swanson, P., \& Chan, W. K. (1994). Extraordinary salmon growth. Nature, 371(6494), 209-210.

Devlin, R. H. (1997) Transgenic salmonids. In: Houdebine, LM (ed.), Transgenic Animals: Generation and Use. (pp. 105117) Harwood Academic Publishers, Amsterdam, The Netherlands.

Devlin, R. H., Biagi, C. A., Yesaki, T. Y., Smailus, D. E., \& Byatt, J. C. (2001). Growth of domesticated transgenic fish. Nature, 409(6822), 781-782.

Du, S. J., Gong, Z. Y., Fletcher, G. L., Shears, M. A., King, M. J., Idler, D. R., \& Hew, C. L. (1992). Growth enhancement in transgenic Atlantic salmon by the use of an 'all fish' chimeric growth hormone gene construct. Biotechnology, 10(2), 176-181.

Dunham, R. A., Eash, J., Askins, J., \& Townes, T. M. (1987). Transfer of the metallothionein-human growth hormone fusion gene into channel catfish. Transactions of the American Fisheries Society, 116(1), 87-91.

Dunham, R. A., Warr, G., Nichols, A., Duncan, P. L., Argue, B., Middleton, D., \& Kucuktas, H. (2002). Enhanced bacterial disease resistance of transgenic channel catfish, Ictalarus punctatus, possessing cecropin genes. Marine Biotechnology, 4(3), 338-44.

Dunham, R. (2009). Transgenic fish resistant to infectious diseases, their risk and prevention of escape into the environment and future candidate genes for disease transgene manipulation. Comparative Immunology, Microbiology and Infectious Diseases, 32(2), 139-161.

Espino-Saldaña, A. E., Durán-Ríos, K., Olivares-Hernandez, E., Rodríguez-Ortiz, R., Arellano-Carbajal, F., \& MartínezTorres, A. (2020). Temporal and spatial expression of zebrafish mctp genes and evaluation of frameshift alleles of mctp2b. Gene, 738, 144371.

Foley, J. E., Maeder, M. L., Pearlberg, J., Joung, J. K., Peterson, R. T., \& Yeh, J. R. J. (2009). Targeted mutagenesis in zebrafish using customized zinc-finger nucleases. Nature protocols, 4(12), 1855-1868.

Gaiano, N., Allende, M., Amsterdam, A., Kawakami, K., \& Hopkins, N. (1996). Highly efficient germ-line transmission of proviral insertions in zebrafish. Proceedings of the National Academy of Sciences, 93(15), 7777-7782.

Goldman, D., Hankin, M., Li, Z., Dai, X., \& Ding, J. (2001). Transgenic zebrafish for studying nervous system development and regeneration. Transgenic Research, 10(1), 21-33.

Gómez, A. (2018) Genetically modified fish in aquaculture. Frontiers in Sciences and Engineering, 8(1),61-68.

Grabarek, J.B., Plusa, B., Glover, D.M., \& Zernicka-Goetz, M. (2002). Efficient delivery of dsRNA into zona-enclosed mouse oocytes and preimplantation embryos by 
electroporation. Genesis, 32(4), 269-276.

Gui, T., Zhang, J., Song, F., Sun, Y., Xie, S., Yu, K. \& Xiang, J. (2016). CRISPR/Cas9-mediated genome editing and mutagenesis of EcChi4 in Exopalaemon carinicauda. G3: Genes, Genomes, Genetics, 6(11), 3757-3764.

Hew, C. L., Davies, P. L., \& Fletcher, G. (1992). Antifreeze protein gene transfer in Atlantic salmon. Molecular marine biology and biotechnology, 1(4-5), 309-317.

Hew, C. L., Fletcher, G. L., \& Davies, P. L. (1995). Transgenic salmon: tailoring the genome for food production. Journal of Fish Biology, 47, 1-19.

Hew, C., Poon, R., Xiong, F., Gauthier, S., Shears, M., King, M., Davies, P., \& Fletcher, G. (1999). Liver specific and seasonal expression of transgenic Atlantic salmon harboring the winter flounder antifreeze protein gene. Transgenic Research, 8(6), 405-414.

Hostetler, H., Peck, S. \& Muir, W. (2003) High efficiency production of germ-line transgenic Japanese medaka (Oryzias latipes) by electroporation with direct currentshifted radio frequency pulses. Transgenic Research, 12, 413-424

Hu, Y., Guo, X., Zhou, Y., Cao, G., Gong, C., \& Xue, R. (2012). Exploration of transgenic method for goldfish and loach with the piggyBac transposon. Journal Of Fisheries Of China, 36(10), 1473-1481.

Hung, K. W., Suen, M. F., Chen, Y. F., Cai, H. B., Mo, Z. X., \& Yung, K. K. (2012). Detection of water toxicity using cytochrome P450 transgenic zebrafish as live biosensor: For polychlorinated biphenyls toxicity. Biosensors and Bioelectronics, 31(1), 548-553.

Jahner, D., \& Jaenisch, R. (1985). Chromosomal position and specific demethylation in enhancer sequences of germ line-transmitted retroviral genomes during mouse development. Molecular and Cellular Biology, 5(9), 2212-2220.

Jinek, M., Chylinski, K., Fonfara, I., Hauer, M., Doudna, J.A. \& Charpentier, E. (2012). A programmable dual RNAguided DNA endonuclease in adaptive bacterial immunity. Science, 337(6096), 816-821.

Joung, J., \& Sander, J. (2012). TALENs: a widely applicable technology for targeted genome editing. Nature Reviews Molecular Cell Biology, 14(1), 49-55.

Ju, B., Chong, S., He, J., Wang, X., Xu, Y., \& Wan, H., Tong, Y., Yan, T., Korzh, V., \& Gong, Z. (2003). Recapitulation of fast skeletal muscle development in zebrafish by transgenic expression of GFP under the mylz2 promoter. Developmental Dynamics, 227(1), 14-26.

Kera, S. A., Agerwala, S. M. \& Horne, J. H. (2010). The temporal resolution of in vivo electroporation in zebrafish: A method for time-resolved loss of function. Zebrafish, 7(1), 97-108.

Khalil, K., Elayat, M., Khalifa, E., Dag, S., Elaswad, A., Miller, M., Abdelrahman, H., Ye, Z., Odin, R., Drescher, D., \& Vo, K. (2017) Generation of Myostatin Gene- Edited Channel Catfish (Ictalurus punctatus) via Zygote Injection of CRISPR/Cas9 System. Scientific Reports, 7(1), 1-12.

Kim, K., Park, H., Kim, J., Kim, S., Williams, D., Kim, M., Jung, Y., Teraoka, H., Park, H., Choy, H., Shin, B. A., \& Choi, S. (2013). Cyp1a reporter zebrafish reveals target tissues for dioxin. Aquatic Toxicology, 134, 57-65.

Kishimoto, K., Washio, Y., Yoshiura, Y., Toyoda, A., Ueno, T., Fukuyama, H., Kato, K., \& Kinoshita, M. (2018). Production of a breed of red sea bream Pagrus major with an increase of skeletal muscle muss and reduced body length by genome editing with CRISPR/Cas9.
Aquaculture, 495, 415-427.

Kurita, K., Burgess, S. M., \& Sakai, N., (2004). Transgenic zebrafish produced by retroviral infection of in vitrocultured sperm. Proceedings of the National Academy of Sciences, 101, 1263-1267.

Krasnov, A., Agren, J. J., Pitaknen, T. I. \& Molsa, H. (1999). Transfer of growth hormone (GH) transgenes into Arctic charr (Salvelinus alpinus L.). II. Nutrient partitioning in rapidly growing fish. Genetic analysis: Biomolecular engineering, 15(3-5), 99-105.

Kumar, S. R., Ahmed, V. I., Parameswaran, V., Sudhakaran, R., Babu, V. S., \& Hameed, A. S. (2008). Potential use of chitosan nanoparticles for oral delivery of DNA vaccine in Asian sea bass (Lates calcarifer) to protect from Vibrio (Listonella) anguillarum. Fish \& Shellfish Immunology, 25(1-2), 47-56.

Kusik, B. W., Carvan III, M. J., \& Udvadia, A. J. (2008). Detection of mercury in aquatic environments using EPRE reporter zebrafish. Marine Biotechnology, 10(6), 750 - 757.

Lee, S. G., Lee, J. H., Kang, S. H., \& Kim, H. J. (2013). Marine Antifreeze Proteins: Types, Functions and Applications. Marine Proteins and Peptides: Biological Activities and Applications, 667-694.

Lee, O., Green, J., \& Tyler, C. (2014). Transgenic fish systems and their application in ecotoxicology. Critical Reviews in Toxicology, 45(2), 124-141.

Li, M. H., Yang, H. H., Li, M. R., Sun, Y. L., Jiang, X. L., Xie, Q. P., Wang, T. R., Shi, H. J., Sun, L. N., Zhou, L. Y., \& Wang, D. S. (2013). Antagonistic roles of Dmrt1 and Foxl2 in sex differentiation via estrogen production in tilapia as demonstrated by TALENs. Endocrinology, 154(12), 48144825.

Li, M., Yang, H., Zhao, J., Fang, L., Shi, H., Li, M., Sun, Y., Zhang, X., Jiang, D., Zhou, L., \& Wang, D. (2014). Efficient and heritable gene targeting in tilapia by CRISPR/Cas9. Genetics, 197(2), 591-599.

Lin, S., Gaiano, N., Culp, P., Burns, J. C., Friedmann, T., Yee, J. K., \& Hopkins, N. (1994). Integration and germ-line transmission of a pseudotyped retroviral vector in zebrafish. Science, 265(5172), 666-669.

Lin, W. C., Chang, H. Y., \& Chen, J. Y. (2016). Electrotransfer of the tilapia piscidin 3 and tilapia piscidin 4 genes into skeletal muscle enhances the antibacterial and immunomodulatory functions of Oreochromis niloticus. Fish \& Shellfish Immunology, 50, 200-209.

Ma, Q., \& Lu, A. Y. (2007). CYP1A induction and human risk assessment: an evolving tale of in vitro and in vivo studies. Drug metabolism and disposition, 35(7), 10091016.

Martinez, R., Juncal, J., Zaldivar, C., Arenal, A., Guillen, I., Morera, V., Carrillo, O., Estrada, M., Morales, A., \& Estrada, M. P. (2000). Growth efficiency in transgenic tilapia (Oreochromis sp.) carrying a single copy of an homologous cDNA growth hormone. Biochemical and Biophysical Research Communications, 267(1) 466-472.

Weifeng, M., Yaping, W., Wenbo, W., Bo, W., Jianxin, F., \& Zuoyan, Z. (2004). Enhanced resistance to Aeromonas hydrophila infection and enhanced phagocytic activities in human lactoferrin-transgenic grass carp (Ctenopharyngodon idellus). Aquaculture, 242(1-4), 93103.

Mattingly, C., McLachlan, J., \& Toscano, W. (2001). Green fluorescent protein (GFP) as a marker of aryl hydrocarbon receptor (AhR) function in developing zebrafish (Danio rerio). Environmental Health 
Perspectives, 109(8), 845-849.

Miller, J. C., Tan, S., Qiao, G., Barlow, K. A., Wang, J., Xia, D. F., Meng, X., Paschon, D. E., Leung, E., Hinkley, S. J., Dulay, G. P., Hua, K. L., Ankoudinova, I., Cost, G. J., Urnov, F. D., Zhang, H. S., Holmes, M. C., Zhang, L., Gregory, P. D., \& Rebar, E. J. (2011). A TALE nuclease architecture for efficient genome editing. Nature Biotechnology, 29(2), 143-150.

Mohanta, R., Jayasankar, P., Mahapatra, K. D., Saha, J. N., \& Barman, H. K. (2014). Molecular cloning, characterization and functional assessment of the myosin light polypeptide chain 2 (mylz2) promoter of farmed carp, Labeo rohita. Transgenic research, 23(4), 601-607.

Mori, T., \& Devlin, R. H. (1999). Transgene and host growth hormone gene expression in pituitary and nonpituitary tissues of normal and growth hormone transgenic salmon. Molecular and cellular endocrinology, 149(1-2), 129-139.

Nam, Y. K., Noh, J. K., Cho, Y. S., Cho, H. J., Cho, K. N., Kim, C. G., \& Kim, D. S. (2001). Dramatically accelerated growth and extraordinary gigantism of transgenic mud loach Misgurnus mizolepis. Transgenic research, 10(4), 353362.

Ng, G. H. B., \& Gong, Z. (2013). GFP transgenic medaka (Oryzias latipes) under the inducible cyp1a promoter provide a sensitive and convenient biological indicator for the presence of TCDD and other persistent organic chemicals. PLoS One, 8(5), e64334.

Ozato, K., Kondoh, H., Inohara, H., Iwamatsu, T., Wakamatsu, Y., \& Okada, T. (1986). Production of transgenic fish: introduction and expression of chicken $\delta$-crystallin gene in medaka embryos. Cell Differentiation, 19(4), 237-244.

Pan, X., Zhan, H., \& Gong, Z. (2008). Ornamental expression of red fluorescent protein in transgenic founders of white skirt tetra (Gymnocorymbus ternetzi). Marine Biotechnology, 10(5), 497-501.

Penman, D. J., lyengar, A., Beeching, A. J., Rahman, A., Sulaiman, Z., \& Maclean, N. (1991). Patterns of transgene inheritance in rainbow trout (Oncorhynchus mykiss). Molecular reproduction and development, 30(3), 201-206.

Pereiro, P., Martinez-Lopez, A., Falco, A., Dios, S., Figueras, A., Coll, J., Novoaa, B., \& Estepa, A. (2012). Protection and antibody response induced by intramuscular DNA vaccine encoding for viral haemorrhagic septicaemia virus (VHSV) G glycoprotein in turbot (Scophthalmus maximus). Fish \& shellfish immunology, 32(6), 10881094.

Peters, K. G., Rao, P. S., Bell, B. S., \& Kindman, L. A. (1995). Green fluorescent fusion proteins: powerful tools for monitoring protein expression in live zebrafish embryos. Developmental biology, 171(1), 252-257.

Petersen, K., Fetter, E., Kah, O., Brion, F., Scholz, S., \& Tollefsen, K. E. (2013). Transgenic (cyp19a1b-GFP) zebrafish embryos as a tool for assessing combined effects of oestrogenic chemicals. Aquatic toxicology, 138, 88-97.

Pitkänen, T. I., Krasnov, A., Teerijoki, H., \& Molsa, H. (1999a). Transfer of growth hormone (GH) transgenes into Arctic charr (Salvelinus alpinus L.) I. Growth response to various $\mathrm{GH}$ constructs. Genetic Analysis: Biomolecular Engineering, 15(3-5), 91-98.

Pitkänen, T.I., Krasnov, A., Reinisalo, M., \& Mölsä, H. (1999b) Transfer and expression of glucose transporter and hexokinase genes in salmonid fish. Aquaculture, 173(14), 319-332.

Potter, H., \& Heller, R. (2018). Transfection by electroporation. Current protocols in molecular biology, 121(1), 9-3.

Powers, D. A., Gonzalez-Villasenor, L. I., Zhang, P. J., Chen, T. T., \& Dunham, R. A. (1991). Studies on transgenic fish: gene transfer, expression, and inheritance. Biotechnology (Reading, Mass.), 16, 307.

Qin, Z., Li, Y., Su, B., Cheng, Q., Ye, Z., Perera, D. A., Fobes, M., Shang, M., \& Dunham, R. A. (2016). Editing of the Luteinizing Hormone Gene to Sterilize Channel Catfish, Ictalurus punctatus, Using a Modified Zinc Finger Nuclease Technology with Electroporation. Marine Biotechnology, 18(2), 255-263.

Rahman, M. A., Mak, R., Ayad, H., Smith, A., \& Maclean, N. (1998). Expression of a novel piscine growth hormone gene results in growth enhancement in transgenic tilapia (Oreochromis niloticus). Transgenic research, 7(5), $357-$ 370.

Rasal, K. D., Chakrapani, V., Patra, S. K., Ninawe, A. S., Sundaray, J. K., Jayasankar, P., \& Barman, H. K. (2016). Status of transgenic fish production with emphasis on development of food fishes and novel color varieties of ornamental fish: implication and future perspectives. Journal of FisheriesSciences.com, 10(3), 52.

Raz, E., van Luenen, H.G.A.M., Schaerringer, B., Plasterk, R.H., \& Driever, W. (1997). Raz, E., van Luenen, H. G., Schaerringer, B., Plasterk, R. H., \& Driever, W. (1998). Transposition of the nematode Caenorhabditis elegans Tc3 element in the zebrafish Danio rerio. Current Biology, 8(2), 82-88.

Robl, J., Wang, Z., Kasinathan, P., \& Kuroiwa, Y. (2007). Transgenic animal production and animal biotechnology. Theriogenology, 67(1), 127-133.

Sakuma, T., Nishikawa, A., Kume, S., Chayama, K., \& Yamamoto, T. (2014). Multiplex genome engineering in human cells using all-in-one CRISPR/Cas9 vector system. Scientific reports, 4(1), 1-6.

Sanderson, J. \& Humphries, F. (2015). Unnaturally natural: inventing and eating genetically engineered AquAdvantage ${ }^{\circledR}$ salmon and the paradox of nature. In C., Lawson, \& B., Charnley (Eds.), Intellectual Property and Genetically Modified Organisms: A Convergence in Laws. (pp. 185-208).

Sarmasik, A., Chun, C. Z., Jang, I. K., Lu, J. K., \& Chen, T. T. (2001). Production of transgenic live-bearing fish and crustaceans with replication-defective pantropic retroviral vectors. Marine Biotechnology, 3(1), S177S184.

Sarmasik, A., Warr, G., \& Chen, T. T. (2002). Production of transgenic medaka with increased resistance to bacterial pathogens. Marine biotechnology, 4(3), 310-322.

Satam, S. B., Sawant, N. H., Ghughuskar, M. M., Sahastrabuddhe, V. D., Naik, V. V., Pagarkar, A. U., Chogale, N. D., Metar, S. Y., Shinde, K. M., Sadawarte, V. R., Sawant, A. N., Singh, H., Sawant, P. A., Patil, V. K., Rane, A.D., Haldankar, P. M., \& Bhattacharyya, T. (2018) Ornamental Fisheries: A new Avenue to Supplement Farm Income. Advanced Agricultural Research \& Technology Journal, 2(2),193-197.

Sin, F. Y. T., Walker, S. P., Symonds, J. E., Mukherjee, U. K., Khoo, J. G. I., \& Sin, I. L. (2000). Electroporation of salmon sperm for gene transfer: efficiency, reliability, and fate 
of transgene. Molecular Reproduction and Development: Incorporating Gamete Research, 56(S2), 285-288.

Shears, M. A. (1991). Transfer, expression, and stable inheritance of antifreeze protein genes in Atlantic salmon (Salmo salar). Molecular Marine Biology and Biotechnology, 1, 58-63.

Sin, F. Y. T., Mukherjee, U. K., Walker, L., \& Sin, I. L. (1997). The application of gene transfer techniques to marine resource management: recent advances, problems and future directions. Hydrobiologia, 352(1-3), 263-278.

Singh, B., Mal, G., Gautam, S. K., \& Mukesh, M. (2019). Steps Toward Sustainable Livestock Development: Technologies to Boost Indigenous Livestock. In Advances in Animal Biotechnology (pp. 485-499). Springer, Cham.

Slyck K. M. V. (2017). Salmon with a Side of Genetic Modification: The FDA's Approval of AquAdvantage Salmon and Why the Precautionary Principle is Essential for Biotechnology Regulation. Seattle University Law Review, 41(1), 311-336.

Spectrum Brand Pet. (2020). GloFish ${ }^{\circledR}$ Brand of Spectrum Brands Pet LLC Expands Fluorescent Fish Offerings in Canada. Prnewswire.com. Retrieved 15 December 2020, from https://www.prnewswire.com/newsreleases/glofish-brand-of-spectrum-brands-pet-llcexpands-fluorescent-fish-offerings-in-canada300757248.html.

Stevens, C., Croft, D., Paull, G., \& Tyler, C. (2017). Stress and welfare in ornamental fishes: what can be learned from aquaculture?. Journal of Fish Biology, 91(2), 409-428.

Sun, Y., Zhang, M., Liu, C., Qiu, R., \& Sun, L. (2012). A divalent DNA vaccine based on Sia10 and OmpU induces cross protection against Streptococcus iniae and Vibrio anguillarum in Japanese flounder. Fish \& Shellfish Immunology, 32(6), 1216-1222.

Tafalla, C., Estepa, A., \& Coll, J. (2006). Fish transposons and their potential use in aquaculture. Journal of Biotechnology, 123(4), 397-412.

The Fish Site (2020). AquaBounty unveils 50,000 tonne target. Thefishsite.com. Retrieved 13 December 2020, from https://thefishsite.com/articles/aquabounty-unveils-50000-tonne-target.

Tonelli, F. M. P., Lacerda, S., Tonelli, F. C. P., Costa, G., de França, L., \& Resende, R. (2017a). Progress and biotechnological prospects in fish transgenesis. Biotechnology Advances, 35(6), 832-844.

Tonelli, F. M. P., Lacerda, S. M. S. N., Procópio, M. S., Lemos, B. L. S., de França, L. R., \& Resende, R. R. (2017b). Gene delivery to Nile tilapia cells aiming transgenesis and the role of PI3K-c2 $\alpha$ in angiogenesis. Scientific Report, 7, 44317.

Van Eenennaam, A., \& Muir, W. (2011). Transgenic salmon: a final leap to the grocery shelf?. Nature Biotechnology, 29(8), 706-710.

Van Eenennaam, A. (2017). Genetic modification of food animals. Current Opinion In Biotechnology, 44, 27-34.

Vick, B. M., Pollak, A., Welsh, C., \& Liang, J. O. (2012). Learning the scientific method using GloFish. Zebrafish, 9(4), 226241.

Wagle, M., \& Jesuthasan, S. (2003). Baculovirus-mediated gene expression in zebrafish. Marine biotechnology, 5(1), 58-63.
Ward, A. C. \& Lieschke, G. J. (2002). The zebrafish as a model system for human disease. Frontiers in Bioscience, 7 , 827-833.

Wargelius, A., Leininger, S., Skaftnesmo, K. O., Kleppe, L., Andersson, E., Taranger, G. L., Schulz, R. W., \& Edvardsen, R. B. (2016). Dnd knockout ablates germ cells and demonstrates germ cell independent sex differentiation in Atlantic salmon. Scientific Reports, 6(1), 1-8.

Wang, R., Zhang, P., Gong, Z., \& Hew, C. L. (1995). Expression of the antifreeze protein gene in transgenic goldfish (Carassius auratus) and its implication in cold adaptation. Molecular Marine Biology and Biotechnology, 4(1), 20-26.

Winn, R. N., Norris, M. B., Brayer, K. J., Torres, C., \& Muller, S. L. (2000). Detection of mutations in transgenic fish carrying a bacteriophage $\lambda$ cll transgene target. Proceedings of the National Academy of Sciences, 97(23), 12655-12660.

Wu, S., Hwang, P., Hew, C., Wu, J. (1998). Effect of Antifreeze Protein on Cold Tolerance in Juvenile Tilapia (Oreochromis mossambicus Peters) and Milkfish (Chanos chanos Forsskal). Zoological Studies, 37(1), 39-44.

Xu, Q., Stemple, D., \& Joubin, K. (2008). Microinjection and cell transplantation in zebrafish embryos. In Molecular Embryology (pp. 513-520). Humana Press.

Yazawa, R., Hirono, I., \& Aoki, T. (2006). Transgenic zebrafish expressing chicken lysozyme show resistance against bacterial diseases. Transgenic research, 15(3), 385-391.

Yu, H., Li, H., Li, Q., Xu, R., Yue, C., \& Du, S. (2019). Targeted gene disruption in Pacific oyster based on CRISPR/Cas9 ribonucleoprotein complexes. Marine Biotechnology, 21(3), 301-309.

Zbikowska, H. M. (2003). Fish can be first-advances in fish transgenesis for commercial applications. Transgenic Research, 12(4), 379-389.

Zeng, Z., Liu, X., Seebah, S., \& Gong, Z. (2005). Faithful expression of living color reporter genes in transgenic medaka under two tissue-specific zebrafish promoters. Developmental dynamics: an official publication of the American Association of Anatomists, 234(2), 387-392.

Zeng, Z., Shan, T., Tong, Y., Lam, S., \& Gong, Z. (2005). Development of Estrogen-Responsive Transgenic Medaka for Environmental Monitoring of Endocrine Disrupters. Environmental Science \& Technology, 39(22), 9001-9008.

Zhang, F., Wen, Y., \& Guo, X. (2014). CRISPR/Cas9 for genome editing: progress, implications and challenges. Human Molecular Genetics, 23(1), 40-46.

Zhang, P. J., Hayat, M., Joyce, C., Gonzalez-Villasenor, L. I., Lin, C. M., Dunham, R. A., Chen, T. T., \& Powers, D. A. (1990). Gene transfer, expression and inheritance of pRSVrainbow trout-GH cDNA in the common carp, Cyprinus carpio (Linnaeus). Molecular Reproduction and Development, 25(1), 3-13.

Zhu, Z., He, L., \& Chen, S. (1985). Novel gene transfer into the fertilized eggs of gold fish (Carassius auratus L. 1758). Journal of Applied Ichthyology, 1(1), 31-34. 